\title{
The effect of an exogenous protease on the fermentation and nutritive value of high-moisture corn
}

\author{
L. Kung Jr., ${ }^{* 1}$ M. C. Windle, ${ }^{*}$ and N. Walkert \\ *Department of Animal and Food Sciences, University of Delaware, Newark 19717 \\ †AB Vista, a Division of AG Agri Ltd., Marlborough, Wiltshire, SN8 4AN, United Kingdom
}

\begin{abstract}
The objective of this study was to determine if treating high-moisture corn at harvest with an exogenous protease could accelerate the increase in in vitro ruminal starch degradation that is normally found with advancing times of ensiling. Ground high-moisture corn (HMC; $73 \%$ dry matter) was untreated or treated with an exogenous protease to achieve a final concentration of $2,000 \mathrm{mg}$ of protease $/ \mathrm{kg}$ of fresh corn. Corn was ensiled in laboratory-scale bags (approximately $500 \mathrm{~g}$ ) that were evacuated of air, heat-sealed, and stored at 22 to $23^{\circ} \mathrm{C}$ for 70 and $140 \mathrm{~d}$. Samples of freshly treated corn samples were collected to represent d 0 samples. Treatment of HMC with protease did not affect the gross populations of lactic acid bacteria or yeasts throughout the ensiling period. Treatment of HMC with protease resulted in higher concentrations of lactic acid and ethanol after 70 but not $140 \mathrm{~d}$ of ensiling. Concentrations of crude protein, water-soluble carbohydrates, and starch were unaffected by treatment with protease within each sampling day. After 70 or $140 \mathrm{~d}$ of ensiling, HMC that was treated with protease had higher concentrations of soluble protein (as a \% of crude protein) and $\mathrm{NH}_{3}-\mathrm{N}$, and had lower concentrations of prolamin protein, compared with untreated corn. In vitro rumen degradability (7-h incubation) of starch was greater in protease-treated versus untreated corn at all sampling days but the difference was more pronounced after 70 and $140 \mathrm{~d}$ compared with d 0 . Concentrations of soluble protein and $\mathrm{NH}_{3}-\mathrm{N}$ were positively correlated with in vitro starch degradation. Conversely, the concentrations of prolamin protein in HMC were negatively correlated with in vitro starch degradation. Treating HMC with an exogenous protease could be a method to obtain greater potential for ruminal starch fermentation after a relatively short period of ensiling.
\end{abstract}

Key words: high-moisture corn, protease, starch digestibility

Received September 9, 2013.

Accepted November 9, 2013.

${ }^{1}$ Corresponding author: lksilage@udel.edu

\section{INTRODUCTION}

High-moisture corn (HMC) is a popular feed for ruminants because its removes the need for drying and can be harvested earlier, compared with dry corn production practices (Mader and Erickson, 2006). However, prolamin proteins form a matrix with starch in the corn kernel and, because they are hydrophobic, they can impede access to starch by rumen microorganisms (Owens et al., 1986; Huntington et al., 2006). For this reason, the digestibility of starch in HMC can be substantially lower at harvest compared with the same HMC ensiled for prolonged periods (Benton et al., 2005). Although the rate (Stock et al., 1991) and extent of starch (or DM) digestion (Benton et al., 2005) in HMC has been shown to improve with advancing ensiling time, Ferraretto et al. (2013) reported that HMC may need up to 8 mo of ensiling to reach maximum ruminal starch digestibility. Hoffman et al. (2011) reported that proteolytic mechanisms are induced by ensiling and are most likely responsible for increases in starch digestibility. They also reported that ensiling reduced all $\alpha, \beta$ and $\delta$ prolamin-zein subunits of the starch-protein matrix by 10 to $40 \%$. The degradation of the $\gamma$ prolamin-zein subunits of the starch-protein matrix of HMC was more extensive, with a $60 \%$ reduction. Because $\gamma$ prolaminzeins are surface localized and primarily responsible for cross-linking starch granules together, the degradation of $\gamma$ zeins in HMC suggests that clusters of starch granules dissociate as a result of silage fermentation, which increases the surface area for bacterial attachment in the rumen (Huntington et al., 2006). Young et al. (2012) recently reported that adding exogenous proteases to whole-corn plants at harvest accelerated the proteolytic processes during ensiling, resulting in a rapid increase in ruminal in vitro starch degradation with increasing ensiling time. However, it is unknown whether the addition of exogenous proteases can cause a similar improvement in starch degradation in HMC. Our hypothesis was that an exogenous protease enzyme would yield the same effect of increasing starch digestion in HMC as it has in whole-plant corn silage. Thus, the objective of this research was to determine the effects of treating 
HMC with an exogenous protease formulation on fermentation and in vitro starch degradation after various lengths of ensiling.

\section{MATERIALS AND METHODS}

Ground HMC, from an unknown hybrid, was obtained from a regional dairy farm and transported to the University of Delaware within $2 \mathrm{~h}$ of harvest. The HMC was separated into 10 lots of HMC, each containing $7 \mathrm{~kg}$ of fresh HMC. Five lots of HMC were treated with $0.1 M$ phosphate buffer ( $\mathrm{pH} 5.5,5 \% \mathrm{vol} / \mathrm{wt}$ of fresh forage, CT treatment) and 5 lots were treated with the same phosphate buffer containing an experimental acid protease, resulting in 2,000 $\mathrm{mg}$ of protease $/ \mathrm{kg}$ of fresh HMC (AB Vista, Wiltshire, UK; EZ treatment). The protease was the same E85 formulation that was used in the study by Young et al. (2012) from Aspergillus niger with a low $\mathrm{pH}$ (3) optimum for activity. At $\mathrm{pH} 3$ and $50^{\circ} \mathrm{C}$, the protease activity was reported, by Young et al. (2012), to be 1,865 $\mathrm{U}$ of activity/mg of solids. Activity decreased as $\mathrm{pH}$ increased; at $\mathrm{pH} 4$, activity was approximately $50 \%$ of activity at $\mathrm{pH} 3$, and at $\mathrm{pH}$ 5 , activity was approximately $20 \%$ of activity at $\mathrm{pH} 3$. Each lot of HMC was constantly mixed while spraying the buffer or buffer plus protease solution onto it. Samples of fresh HMC (after treatment) from each lot served as replicate samples for d 0. After treatment, approximately $500 \mathrm{~g}$ of HMC was placed into 2 nylonpolyethylene bags (3.5-mil embossed pouches, $15.2 \times$ $30.5 \mathrm{~cm}$; Doug Care Equipment Inc., Springville, CA) from each lot of HMC. Bags containing the HMC were evacuated to remove air and heat-sealed using a Best Vac vacuum machine (distributed by Doug Care Equipment Inc.). All bags were ensiled for 70 and $140 \mathrm{~d}$ at 22 to $23^{\circ} \mathrm{C}$. Five replicated bag silos were opened for each treatment at each silo opening.

Fresh and ensiled HMC were analyzed for DM by drying samples in a forced-air oven at $60^{\circ} \mathrm{C}$ for $48 \mathrm{~h}$. To prepare water extracts, representative samples of fresh and ensiled HMC (25 g) were combined with 225 $\mathrm{mL}$ of sterile quarter-strength Ringer Solution (Oxoid BR0052G; Oxoid Ltd., Cambridge, UK) and homogenized for $1 \mathrm{~min}$ on a medium setting in a Proctor-Silex 57171 blender (Hamilton Beach/Proctor-Silex Inc., Glen Allen, VA). A portion of the homogenate was filtered through Whatman 54 filter paper (Whatman Ltd., Florham, NJ) and acidified with 3 drops of $50 \%$ $\mathrm{H}_{2} \mathrm{SO}_{4}$ to reduce the $\mathrm{pH}$ of the extract to $<2.0$, and the water extract was frozen $\left(-20^{\circ} \mathrm{C}\right)$ until further analysis. Water extracts were analyzed for $\mathrm{NH}_{3}-\mathrm{N}$ (Okuda et al., 1965) and water-soluble carbohydrates (WSC; Nelson, 1944). Organic acids and ethanol were determined on the water extracts via HPLC using the method of Muck and Dickerson (1988). Portions of the unacidified water extracts were used for enumeration of microbial populations. Serial dilutions of the water extract were made in sterile quarter-strength Ringer solution and pour-plated in de Man, Rogosa, Sharpe agar (Oxoid CM361, Oxoid Ltd.) for lactic acid bacteria (LAB) and on malt extract agar (acidified to $\mathrm{pH} 3.5$ with lactic acid after autoclaving, Oxoid CM0059, Oxoid Ltd.) for yeasts and molds. Plates were incubated aerobically at $30^{\circ} \mathrm{C}$ for 48 to $72 \mathrm{~h}$ before counting.

The following assays were conducted at Cumberland Valley Analytical Services (Maugansville, MD). A portion of each dried sample was ground through a 1-mm screen using a Udy Cyclone Sample Mill (Udy Corp., Fort Collins, CO). Total $\mathrm{N}$ was determined by combustion of the sample (Leco CNS 2000 Analyzer, Leco Corp., St. Joseph, MI), and CP was calculated by multiplying the resulting total $\mathrm{N}$ by 6.25 . The starch content of each sample was determined using 2-stage, heat-stable $\alpha$-amylase and amyloglucosidase in acetate buffer, according to the methodology described by Hall (2009). A 7-h in vitro starch degradability (IVSD) was performed (Tilley and Terry, 1963) on dried samples ground through a Wiley mill (Thomas Scientific, Swedesboro, NJ) to pass through a $3-\mathrm{mm}$ screen. Samples for IVSD were run in duplicate and replicated on 3 separate days. Ruminal fluid was pooled from 3 lactating cows with rumen fistula, which were fed a standard diet comprising $25 \%$ corn silage, $25 \%$ alfalfa haylage, and $50 \%$ concentrate (DM basis). The amount of soluble protein (\% of CP, SOL-CP) was also determined on 3-mm-ground samples according to methodology described by Krishnamoorthy et al. (1982). In addition, the concentration of prolamin protein in HMC was determined at the University of Wisconsin Soil and Forage Analysis Laboratory (Marshfield, WI) using a modified rapid turbidimetric laboratory procedure, where buffer-soluble proteins were removed using a borate phosphate buffer, prolamins were extracted with tert-butanol, and a Bradford protein assay was used to quantify prolamin proteins solubilized in tertbutanol (Nellis et al., 2013).

The data were analyzed as a $3 \times 2$ factorial arrangement of treatments with factors including 3 lengths of storage $(0,70$, and $140 \mathrm{~d}$ ) and 2 treatments (CT and EZ). Data were analyzed using the Fit model procedure of JMP (SAS Institute Inc., Cary, NC), and differences were reported as significant when $P<0.05$. Main effects were treatment and length of storage, their interaction, and residual error included in the model. Means were separated by the Tukey test $(P \leq 0.05$; Snedecor and Cochran, 1980). 
Table 1. The DM, pH, and chemical composition (DM basis) and microbial composition (fresh weight basis) of fresh high-moisture corn (d 0, after treatment but before ensiling) and ensiled high-moisture corn (d 70 and 140) that was treated with an exogenous protease ${ }^{1}$

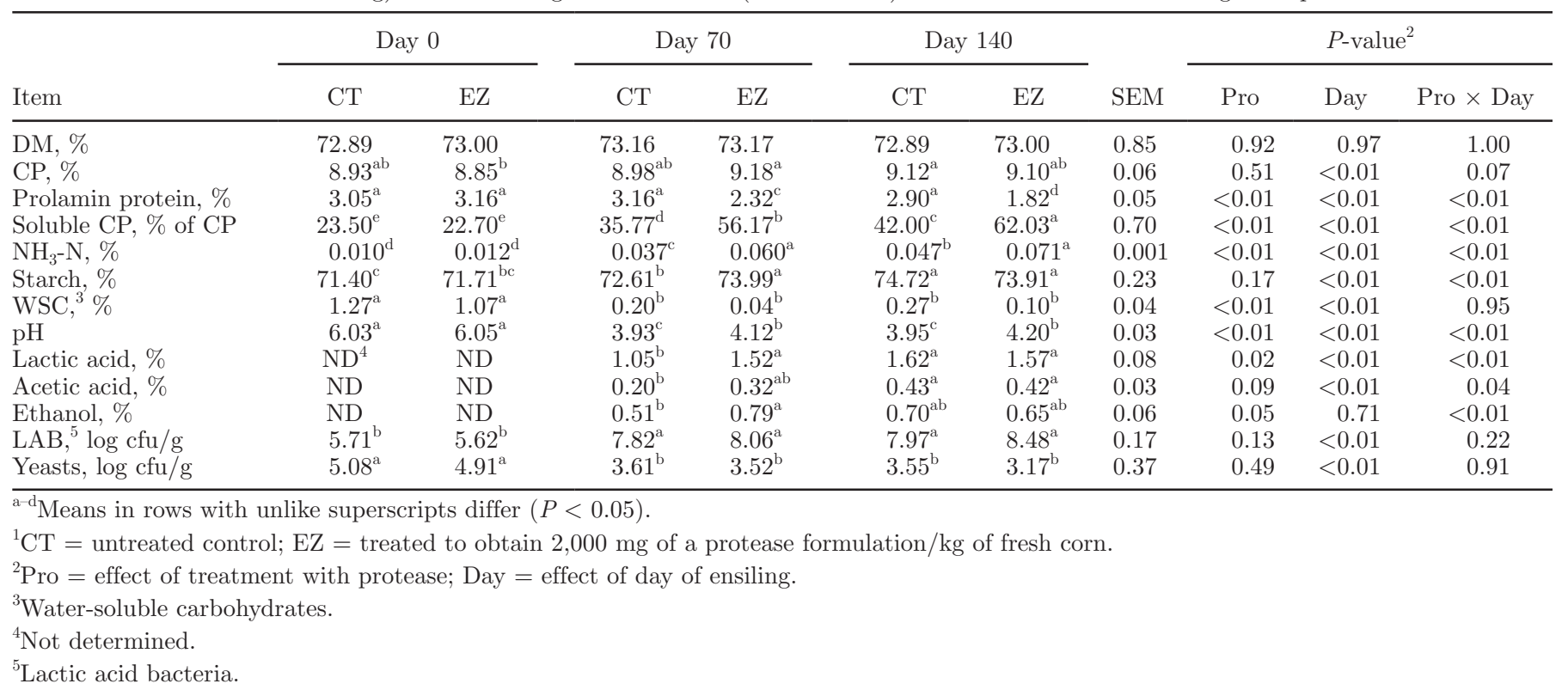

\section{RESULTS AND DISCUSSION}

The DM, chemical composition, $\mathrm{pH}$, concentration of WSC, fermentation profiles, and microbial composition of fresh and ensiled HMC are shown in Table 1. The DM content of HMC was similar between treatments and was unaffected by days of ensiling or treatment with protease. All samples fermented normally, as indicated by decreases in $\mathrm{pH}$ and increases in organic acids with increasing days of ensiling. The $\mathrm{pH}$ of fresh HMC was similar between treatments but higher in EZ than $\mathrm{CT}$ on d 70 (3.93 vs. 4.12) and d 140 (3.95 vs. 4.20). As expected, the concentrations of WSC were low in fresh HMC, and were not affected by treatment with protease within any day of ensiling, although WSC concentrations on d 70 and 140 were numerically less in EZ compared with CT. Concentrations of lactic acid and ethanol were greater in EZ than in CT after $70 \mathrm{~d}$ of ensiling, but were not different after $140 \mathrm{~d}$ of ensiling. Concentrations of acetic acid in HMC were unaffected by treatment with protease after 70 and 140 $\mathrm{d}$ of ensiling (average of $0.43 \%$ ). These data are in minor contrast to the findings of Young et al. (2012) because they reported numerically (but not statistically) greater concentrations of lactic and acetic acids and ethanol in corn silages, treated with the same protease and dose $(2,000 \mathrm{mg} / \mathrm{kg})$ used in the current study, compared with untreated corn silage, suggesting a possible stimulation in the ensiling process. As proteases have stimulated fermentations in the production of ethanol by yeasts (Vidal et al., 2009), these findings are not surprising. Finally, compared with the untreated HMC, treating $\mathrm{HMC}$ with protease did not affect the numbers of epiphytic LAB or yeast within any ensiling time. However, as expected (Taylor and Kung, 2002; Kung et al., 2007), the numbers of LAB increased, whereas numbers of yeasts in HMC declined between d 0 and 70 and remained constant through d 140 .

Treatment with protease did not affect the concentration of CP in HMC. The concentration of CP was lower in fresh HMC compared with ensiled HMC, but this difference was small and most likely not biologically significant. Young et al. (2012) reported that treatment with protease did not alter the concentration of $\mathrm{CP}$ in corn silage. The concentration of prolamin protein was relatively unchanged for $\mathrm{CT}$ when ensiled for 0 or $70 \mathrm{~d}$ and numerically decreased by only 5 percentage units when ensiled for $140 \mathrm{~d}$. In contrast, treating HMC with protease decreased prolamin proteins in HMC by 26 and $42 \%$, respectively, after 70 and $140 \mathrm{~d}$ of fermentation. These data suggest that naturally occurring proteolytic activity on prolamin proteins in CT was very limited. Data also suggest that addition of proteases to HMC can have a direct effect on the reduction of hydrophobic prolamin proteins associated with the starch-protein matrix in HMC, which supports the hypothesis of Hoffman et al. (2011)

We observed interactions between ensiling time and protease treatments for SOL-CP and $\mathrm{NH}_{3}-\mathrm{N}$ concentrations in HMC. The concentration of SOL-CP was similar between fresh CT and EZ (average of 23.10\%) but increased with advancing ensiling times. Increases 
in SOL-CP at 70 and $140 \mathrm{~d}$ were greater for EZ compared with CT. At $140 \mathrm{~d}$ of ensiling, the concentration of SOL-CP was greatest in EZ (62.03\%) compared with $\mathrm{CT}(42.00 \%)$. By difference [units of $\mathrm{CP}=\mathrm{CP} \times(140$ d SOLCP - 0 d SOLCP/100)], 140 d of ensiling time solubilized approximately 1.7 units of $\mathrm{CP}$ in $\mathrm{CT}$. In comparison, addition of a protease to HMC with 140 $\mathrm{d}$ of ensiling solubilized approximately 3.5 units of $\mathrm{CP}$ on DM basis. As a result, the net $\mathrm{CP}$ unit changes in CT and EZ HMC were greater than those in prolamin protein after $140 \mathrm{~d}$ of ensiling. These data suggest that naturally occurring proteolytic activity in HMC and proteolytic activity from the added protease do not solely target prolamin proteins. It is logical to assume that proteolytic activity, whether naturally occurring or aided by a protease, also degrades albumin, globulin, and (or) glutelin protein fractions (Landry et al., 2000). However, specifically which corn proteins are soluble in a borate phosphate buffer (Krishnamoorthy et al., 1982) before or after fermentation are unknown.

The concentrations of $\mathrm{NH}_{3}-\mathrm{N}$ in $\mathrm{CT}$ and EZ followed a trend similar to that observed for SOL-CP, except that $\mathrm{NH}_{3}-\mathrm{N}$ did not increase between 70 and $140 \mathrm{~d}$ of ensiling for EZ. Greater increases in concentrations of $\mathrm{NH}_{3}-\mathrm{N}$ and SOL-CP in HMC treated with protease are similar to increases in $\mathrm{NH}_{3}-\mathrm{N}$ and SOL-CP observed in whole-plant corn silage treated with protease as reported by Young et al. (2012). Data from this study and that of Young et al. (2012) suggest that added protease to HMC or corn silage maintains an environment of increased proteolytic activity over a relatively long ensiling period $(140 \mathrm{~d})$. Treatment of HMC with EZ resulted in a small increase in the concentration of starch compared with CT at $70 \mathrm{~d}$ of ensiling but starch concentrations were similar between HMC treatments at $\mathrm{d} 0$ and 140 . There is no logical mechanism by which treating HMC with a protease should alter starch content, supporting the observations of Young et al. (2012), who reported that treating corn silage with an exogenous protease did not affect starch concentration. In vitro starch degradability (Figure 1) of EZ (47.43\%) was greater than CT (44.03\%) before ensiling, suggesting some early or immediate effect of added protease on IVSD. This effect was relatively small and was not observed in a previous study when lower doses of protease $(<2,000 \mathrm{mg} / \mathrm{kg})$ were applied to whole-plant corn silage (Windle et al., 2013). Similar to our findings with corn silage (Young et al., 2012; Windle et al., 2013), IVSD increased in $\mathrm{HMC}$ with advancing time of ensiling in all HMC but the effect was greater in EZ than in CT. Of particular note was the finding that IVSD in EZ was numerically greater after $70 \mathrm{~d}(61.88 \%)$ of ensiling compared with that for CT after $140 \mathrm{~d}(58.34 \%)$ of ensiling. The increase in IVSD with protease treatment

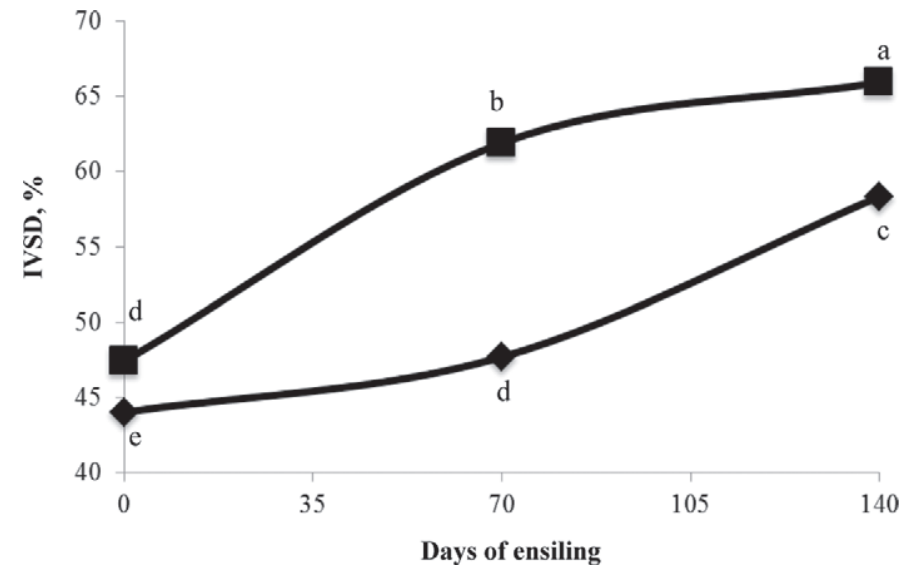

Figure 1. In vitro digestibility of starch (\% of starch, IVSD) in fresh and ensiled high-moisture corn that was untreated (ם) or treated with an exogenous protease $(\bullet)$; SEM $=0.76$. Effect of treatment with protease, $P \leq 0.01$; effect of day of ensiling, $P \leq 0.01$; interaction between treatment with protease and day of ensiling, $P \leq 0.01$. ${ }^{\mathrm{a}-\mathrm{e}}$ Points with unlike letters differ, $P<0.01$.

of HMC agrees with the results observed for corn silage (Young et al., 2012). Results indicate that an exogenous protease accelerates increases in IVSD in fermented HMC or corn silage. Such findings may be important because Ferraretto et al. (2013) suggested that it may take as long as 8 mo for HMC to reach maximal starch degradation potential.

In a past study with corn silages (Der Bedrosian et al., 2012), SOL-CP and $\mathrm{NH}_{3}-\mathrm{N}$ were shown to be highly correlated with IVSD. Similarly, in the current study (Figures $2 \mathrm{a}$ and $2 \mathrm{~b}$ ), both SOL-CP and $\mathrm{NH}_{3}-\mathrm{N}$ were equally and linearly correlated with IVSD $\left(\mathrm{R}^{2}=0.81\right.$ vs. 0.87 for $\mathrm{NH}_{3}-\mathrm{N}$ and SOL-CP, respectively). These observations are similar to the findings reported by Ferraretto et al. (2013) when relationships between SOL$\mathrm{CP}, \mathrm{NH}_{3}-\mathrm{N}$, and IVSD in HMC from measurements from commercial feed and forage testing laboratories were explored. The relationship between the concentration of prolamin proteins and IVSD was also significant (Figure 2c) but negative and, unlike the linear relationships observed between SOL-CP or $\mathrm{NH}_{3}-\mathrm{N}$ and IVSD, the relationship between prolamin proteins and IVSD appears to be second order. This observation is similar to the observations of Benton et al. (2005). Although Benton et al. (2005) did not measure or report prolamin contents of HMC across ensiling times, the study did observe distinct second-order relationships between in situ DM degradation and ensiling time. The data of Benton et al. (2005) suggest that events early in the fermentation of HMC had the greatest effect on starch degradation. The observations in this study are also supported by the detailed measurements of HMC chemistry made by Hoffman et al. (2011). Hoffman et 
(A)

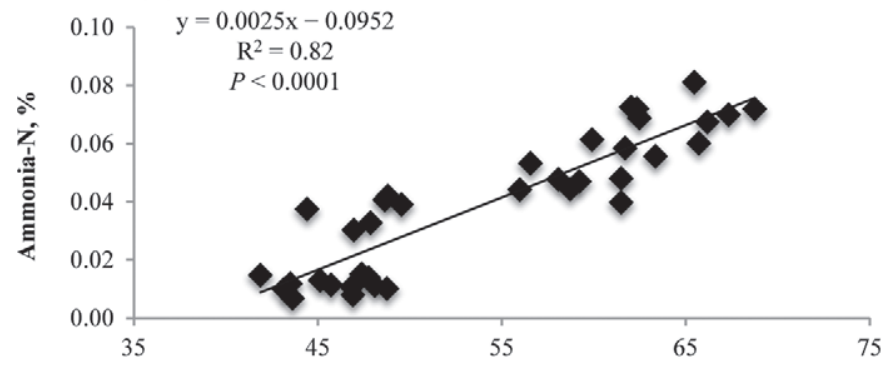

(B)

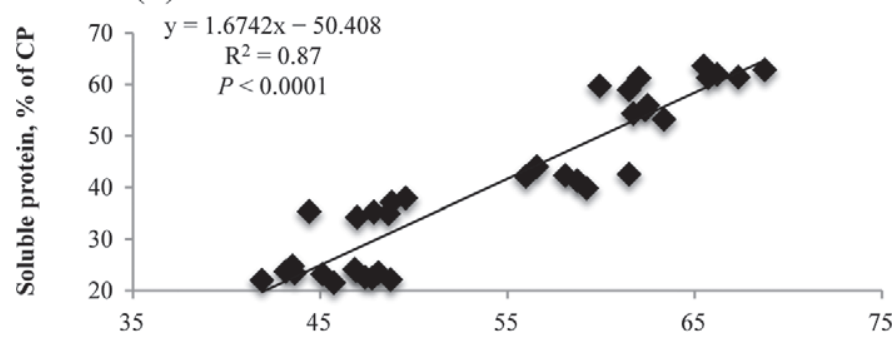

(C)

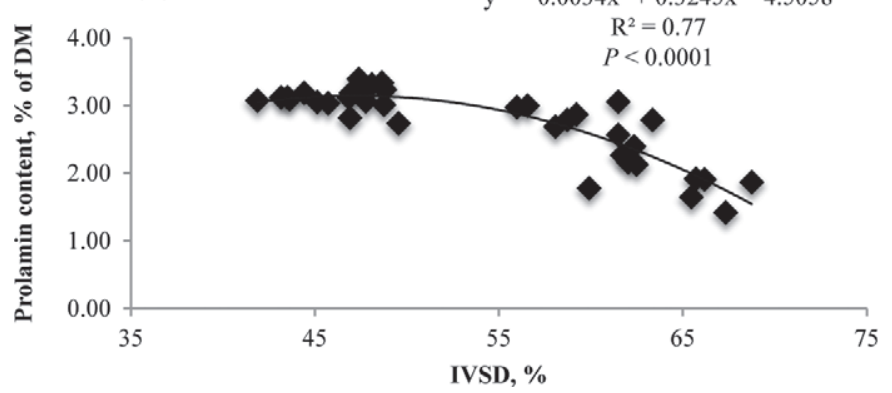

Figure 2. Correlations between (A) $\mathrm{NH}_{3}-\mathrm{N}$ (\% of DM), (B) soluble protein (\% of $\mathrm{CP}$ ), and (C) prolamin protein (\% of $\mathrm{DM})$ and in vitro 7-h starch digestibility (IVSD) high-moisture corn.

al. (2011) reported that $\gamma$ zein is the most highly degraded prolamin in HMC. Because $\gamma$ zein crosslinks and is peripheral to other zein proteins $(\mathrm{Mu}-$ Forster and Wasserman, 1998), it is logical that proteolysis would hydrolyze $\gamma$ zein proteins first, causing the greatest dissociation of starch granules and thereby increasing the surface area of starch available to rumen bacteria (Huntington et al., 2006).

In the past, proteolysis during the ensiling process has generally been considered undesirable in silages because the increase in soluble protein or NPN had been associated with poor animal performance (Bergen et al., 1974; Muck, 1987). Data from this study and other recent reports (Hoffman et al., 2011; Windle et al., 2013) suggest that proteolysis in corn silage and HMC during ensiling is one, if not the primary, mechanism for increasing ruminal starch degradation potential in fermented corn crops. These observations have practical implications. Firkins (2008) suggested that one possible strategy for optimizing milk production from lactating dairy cows would be to maximize ruminal digestion of corn starch while reducing the total dietary starch concentrations. This management practice would be especially beneficial when the price of corn is high. Another practical implication is to utilize the proteolytic mechanism to improve ruminal starch degradation of dry corn, which is commonly reported to be lower than that of comparable HMC (Benton et al., 2005).

Benton et al. (2005) reported that increasing the moisture content of dry (15\%) or drier HMC (24\% moisture) to 28 or $35 \%$ moisture with added water resulted in an improvement in situ DM disappearance (presumably primarily starch) after only 28 to $56 \mathrm{~d}$ of ensiling. Because the available water for microbial fermentation is relatively low in HMC at $24 \%$ moisture, additional water most likely stimulated microbial fermentation, which was accompanied by enhanced proteolytic activity. The challenges with fermenting high-DM crops such as HMC are well known. High DM contents increase the osmotic pressure in fermenting feedstuffs, which decreases the growth rate of lactic acid-producing bacteria (Pitt et al., 1985). As a result, feedstuffs with high DM content ferment slower than those feeds with a lower DM content. Slower growth rates of LAB in dry silages are likely to be further exacerbated by ensiling at low temperatures (Pitt et al., 1985). The combination of limited substrate for fermentation, high DM content, and ensiling at cool temperatures at harvest (often $<10^{\circ} \mathrm{C}$ ) often results in slower fermentations in HMC than would occur in most whole-plant corn silages. Slower fermentations would mean a protracted proteolytic breakdown of the starch-protein matrix in the endosperm. This logic would seem to fit with the findings of Ferraretto et al. (2013), in which some HMC take up to $8 \mathrm{mo}$ to maximize ruminal starch digestion potentials. Data from this study indicate that the potential exists to improve starch digestion in HMC by the addition of a protease at ensiling.

\section{CONCLUSIONS}

Treatment of HMC with an exogenous protease did not markedly affect the overall fermentation of HMC, with the exception of increased concentrations of SOL$\mathrm{CP}$ and $\mathrm{NH}_{3}-\mathrm{N}$. The addition of a protease to HMC before ensiling accelerated the increase in IVSD that is normally observed with increased time of ensiling. These findings confirm previous results obtained when a protease was added to whole-plant corn silage before the time of ensiling. Treatment of HMC with a protease could be one method to obtain highly digestible HMC after a relatively short period of ensiling. 


\section{ACKNOWLEDGMENTS}

This study was partially funded by AB Vista (Wiltshire, UK). The authors thank Jonathan Lim and Caitlyn Merrill (University of Delaware, Newark), and Mariele Agarussi and Lilian Rosa (University of Viçosa, Viçosa, Brazil) for their help with this experiment.

\section{REFERENCES}

Benton, J. R., T. Klopfenstein, and G. E. Erickson. 2005. Effects of corn moisture and length of ensiling on dry matter digestibility and rumen degradable protein. Nebraska Beef Cattle Reports: 31-33. University of Nebraska, Lincoln.

Bergen, W. G., E. H. Cash, and H. E. Henderson. 1974. Changes in nitrogenous compounds of the whole corn plant during ensiling and subsequent effects on dry matter intake by sheep. J. Anim. Sci. 39:629-637.

Der Bedrosian, M. C., K. E. Nestor, and L. Kung Jr. 2012. The effects of hybrid, maturity, and length of storage on the composition and nutritive value of corn silage. J. Dairy Sci. 95:5115-5126.

Ferraretto, L. F., R. D. Shaver, and P. C. Hoffman. 2013. Effect of time of storage on ammonia nitrogen concentration and ruminal in vitro starch digestibility of high-moisture corn. J. Dairy Sci. 96(Suppl. 1):149. (Abstr.)

Firkins, J. L. 2008. Considerations associated with corn processing in dairy rations. Proc. Southwest Nutrition Conference, University of Arizona, Tucson. Accessed Aug. 26, 2013. http://www.cals. arizona.edu/ans/swnmc/Proceedings/2008/ProceedingsList_08. html.

Hall, M. B. 2009. Determination of starch, including maltooligosaccharides, in animal feeds: Comparison of methods and a method recommended for AOAC collaborative study. J. AOAC Int. 92:42-49.

Hoffman, P. C., N. M. Esser, R. D. Shaver, W. K. Coblentz, M. P. Scott, A. L. Bodnar, R. J. Schmidt, and R. C. Charley. 2011. Influence of ensiling time and inoculation on alteration of the starchprotein matrix in high-moisture corn. J. Dairy Sci. 94:2465-2474.

Huntington, G. B., D. L. Harmon, and C. J. Richards. 2006. Sites, rates, and limits of starch digestion and glucose metabolism in growing cattle. J. Anim. Sci. 84(E-Suppl.):E14-E24.

Krishnamoorthy, U., T. V. Muscato, C. J. Sniffen, and P. J. Van Soest. 1982. Borate phosphate procedure as detailed in nitrogen fractions in selected feedstuffs. J. Dairy Sci. 65:217-225.

Kung, L., Jr., R. J. Schmidt, T. E. Ebling, and W. Hu. 2007. The effect of Lactobacillus buchneri 40788 on the fermentation and aero- bic stability of ground and whole high moisture corn. J. Dairy Sci. 90:2309-2314.

Landry, J., S. Delhaye, and C. Damerval. 2000. Improved method for isolating and quantitating $\alpha$-amino nitrogen as nonprotein, true protein, salt-soluble proteins, zeins, and true glutelins in maize endosperm. Cereal Chem. 77:620-626.

Mader, T., and G. Erickson. 2006. Feeding high moisture corn. University of Nebraska, Lincoln. Accessed Aug. 26, 2013. http://www. ianrpubs.unl.edu/pages/publicationD.jsp?publicationId=662.

Mu-Forster, C., and B. P. Wasserman. 1998. Surface localization of zein storage proteins in starch granules from maize endosperm: Proteolytic removal by thermolysin and in vitro cross-linking of granule-associated polypeptides. Plant Physiol. 116:1563-1571.

Muck, R. E. 1987. Dry matter levels on alfalfa silage quality. I. Nitrogen transformation. Trans. ASAE 30:7-14.

Muck, R. E., and J. T. Dickerson. 1988. Storage temperature effects on proteolysis in alfalfa silage. Trans. ASAE 31:1005-1009.

Nellis, S. E., P. C. Hoffman, and R. D. Shaver. 2013. A modified method to quantify prolamin proteins in dry and high-moisture corn. J. Dairy Sci. 96:4647-4652.

Nelson, N. 1944. A photometric adaptation of the Somogyi method for the determination of glucose. J. Biol. Chem. 153:375-380.

Okuda, H., S. Fuji, and Y. Kawashima. 1965. A direct colorimetric method for blood ammonia. Tokushima J. Exp. Med. 12:11-23.

Owens, F. N., R. A. Zinn, and Y. K. Kim. 1986. Limits to starch digestion in the ruminant small intestine. J. Anim. Sci. 63:1634-1648.

Pitt, R. E., R. E. Muck, and R. Y. Leibensperger. 1985. A quantitative model of the ensilage process in lactate silages. Grass Forage Sci. 40:279-303.

Snedecor, G. W., and W. G. Cochran. 1980. Statistical Methods. 6th ed. Iowa State Univ. Press, Ames.

Stock, R. A., M. H. Sindt, R. M. Cleale, and R. A. Britton. 1991. High-moisture corn utilization in finishing cattle. J. Anim. Sci. 69:1645-1656.

Taylor, C. C., and L. Kung Jr. 2002. The effect of Lactobacillus buchneri 40788 on the fermentation and aerobic stability of high moisture corn in laboratory silos. J. Dairy Sci. 85:1526-1532.

Tilley, J. M. A., and R. A. Terry. 1963. A two-stage technique for the in vitro digestion of forage crops. J. Br. Grassl. Soc. 18:104-111.

Vidal, B. C., Jr., K. D. Rausch, M. E. Tumbleson, and V. Singh. 2009 Protease treatment to improve ethanol fermentation in modified dry grind corn processes. Cereal Chem. 86:323-328.

Windle, M., C. Merrill, L. Rosa, M. Agarussi, R. Savage, C. Asay, N. Walker, and L. Kung Jr. 2013. The effects of an exogenous protease on the fermentation and nutritive value of corn silage. J. Dairy Sci. 96(Suppl. 1):313. (Abstr.)

Young, K. M., J. M. Lim, M. C. Der Bedrosian, and L. Kung Jr. 2012. Effect of exogenous protease enzymes on the fermentation and nutritive value of corn silage. J. Dairy Sci. 95:6687-6694. 